Article

\title{
Quantifying Environmental Burdens of Plasters Based on Natural vs. Flue Gas Desulfurization (FGD) Gypsum
}

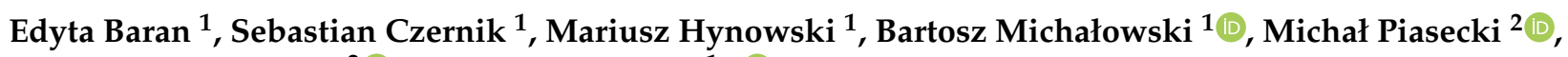 \\ Justyna Tomaszewska ${ }^{2}$ (D) and Jacek Michalak ${ }^{1, *}$ (D) \\ 1 Research and Development Center, Atlas sp. z o.o., 2, Kilinskiego St., 91-421 Lodz, Poland; \\ ebaran@atlas.com.pl (E.B.); sczernik@atlas.com.pl (S.C.); hynowski@atlas.com.pl (M.H.); \\ bmichalowski@atlas.com.pl (B.M.) \\ 2 Building Research Institute, 1, Filtrowa St., 00-611 Warsaw, Poland; m.piasecki@itb.pl (M.P.); \\ j.tomaszewska@itb.pl (J.T.) \\ * Correspondence: jmichalak@atlas.com.pl
}

\section{check for} updates

Citation: Baran, E.; Czernik, S.; Hynowski, M.; Michałowski, B. Piasecki, M.; Tomaszewska, J.; Michalak, J. Quantifying Environmental Burdens of Plasters Based on Natural vs. Flue Gas Desulfurization (FGD) Gypsum. Sustainability 2021, 13, 4298. https:// doi.org/10.3390/su13084298

Academic Editors: Marc A. Rosen, Antonio Caggiano and Cinzia Buratti

Received: 19 February 2021

Accepted: 10 April 2021

Published: 13 April 2021

Publisher's Note: MDPI stays neutral with regard to jurisdictional claims in published maps and institutional affiliations.

Copyright: (c) 2021 by the authors. Licensee MDPI, Basel, Switzerland. This article is an open access article distributed under the terms and conditions of the Creative Commons Attribution (CC BY) license (https:/ / creativecommons.org/licenses/by/ $4.0 /)$.

\begin{abstract}
The ongoing global climate change and the associated environmental degradation pose a threat to Europe and the rest of the world. Raw materials and energy are required to produce building materials, which are used for construction purposes. Resulting buildings and structures generate waste during construction, operation, and demolition, and they emit potentially harmful substances. Thus, the key to achieving climate goals is to support low-emission materials and technologies in the construction sector, significantly impacting the environment. In the European Union, building materials are not yet subject to mandatory sustainability assessment during the assessment and verification of constancy of performance (AVCP). Objective evaluation of construction materials environmental impact requires it to be carried out based on production data on an industrial scale. This article presents the environmental impact of premixed gypsum-based plasters, commonly used in modern construction. Nine environmental indicators (global warming potential (GWP), depletion potential of the stratospheric ozone layer (ODP), acidification potential (AP), eutrophication potential (EP), formation potential of tropospheric ozone (POCP), abiotic depletion potential (ADP)-elements, ADP-fossil fuels, renewable primary energy resources (PERT), and nonrenewable primary energy resources (PERNT)) of premixed gypsum plasters based on natural and flue gas desulfurization (FGD) gypsum were estimated and discussed. Knowledge of the construction products' environmental impact is fundamental for creating reliable databases. AVCP of construction materials in the future will use the data collected during the voluntary environmental impact evaluation.
\end{abstract}

Keywords: construction products assessment; environmental impact; environmental product declaration (EPD); life cycle assessment (LCA); gypsum plasters; natural gypsum; flue gas desulfurization (FGD) gypsum; global warming potential (GWP); sustainable building materials

\section{Introduction}

The coronavirus pandemic shows even more clearly how much the Earth needs a break from excessive human activity. The reduction of greenhouse gas emissions in 2020 in connection with the actions taken in response to the threat of COVID-19 infection will lead to a slight decrease in the annual rate of increase in $\mathrm{CO}_{2}$ concentration in the atmosphere, practically indistinguishable from the natural interannual variability [1]. This information may be a bit surprising when compared to the extreme restrictions we experienced last year due to COVID-19, which, in April 2020, led to daily declines in $\mathrm{CO}_{2}$ emissions from fossil fuels by 11-25\% [2]. However, the real-time data from some specific locations, where the World Meteorological Organization makes observations, indicate that concentrations of carbon dioxide, methane, and nitrous oxide continued to increase in 2020 [1]. A year earlier, i.e., in 2019, their concentrations reached their maximum values: $148 \%, 260 \%$, and 123\% of preindustrial levels, respectively, for $\mathrm{CO}_{2}, \mathrm{CH}_{4}$, and $\mathrm{N}_{2} \mathrm{O}$ [3]. Considering that, in the 
20th century, global materials use increased by eight-fold [4], and nowadays, in the case of many critical raw materials, their deposits will be exhausted within a dozen/several dozen years, the scale of the problem facing our civilization is visible. The current standard of humanity, made possible by the exploitation of natural capital on an unprecedented scale, increases the uncertainty about the future of our planet.

The construction sector and building operations have substantial direct and indirect impacts on the environment. In 2019, the buildings and construction sector were responsible for almost $40 \%$ of energy- and process-related emissions [5]. $\mathrm{CO}_{2}$ emissions from buildings' operation reached the highest level in history at around $10 \mathrm{Gt}$ [6]. For further development, the construction industry needs building materials. Their production requires raw materials and energy, and the resulting buildings generate waste during both construction, operation, and demolition, and they emit potentially harmful substances. The key to achieving climate and social goals is to support low-emission materials and technologies in construction and combine these actions to phasing out the use of fossil fuels [7]. It is also essential to communicate the research results on building's/construction material's environmental impact transparently in prestigious international journals [8]. Data are the most crucial drivers of development today. Their analysis provides information on which the decisions are based. Thus, the data's knowledge and quality at the input determine whether the intended goals are successfully achieved. The construction sector should consider reducing energy consumption and emissivity in two aspects: operational (related to heating, cooling, cooking, lighting, using various devices in buildings) and environmental impact, including the carbon footprint of building materials and the construction process. Improving the thermal insulation of building partitions allows for reducing energy consumption related to heating/cooling. Reducing a building's emissivity is related to replacing devices using solid, liquid, or gaseous fuels for electrical appliances provided electricity from low-emission sources. Reducing the environmental impact/carbon footprint of building materials is related to, e.g., the use of low-energy/low-carbon materials, recycled materials, and the extension of a construction product's service life. The production of a building material always has an impact on the environment. The investigation of greenhouse gas (GHG) emission's temporal distribution showed the importance of the initial, upfront "carbon spike" from the production of building materials and systems [9].

More building materials are produced each year as the needs are growing. More and more people are living in cities. In 2007, the urban population equaled the number of people living in rural areas, while in 2018, the urbanization rate was $55.3 \%$ [10]. As a result of progressive urbanization, by 2050 , almost $70 \%$ of the world's population will live in cities [11]. Today, cities around the world consume about $70 \%$ of all resources and generate more than $75 \%$ of all GHG emissions [11]. The rules for laying down construction products on the European Union market from 1 July 2013 are defined in the Construction Products Directive (CPR) [12]. The manufacturer assesses and verifies the constancy of performance (AVCP) of the construction product concerning its essential characteristics following the relevant technical specification (harmonized European standard within the meaning of CPR or a voluntary European Technical Assessment issued at the manufacturer's request). Following the conducted AVCP, the manufacturer draws up a declaration of performance (DoP) and affixes the CE marking to the product. The construction product's essential characteristics refer to the basic requirements for construction works in Annex I to the CPR. One of the basic requirements is the sustainable use of natural resources. It ensures the reuse and recycling of components, the durability of building structures, and the use of environmentally friendly raw materials and secondary materials. However, the AVCP of construction products in terms of natural resources' sustainable use is not obligatory but only voluntary. The documents on which the assessment is based (European harmonized standard or European Technical Assessment) do not contain the seventh basic requirement.

In 2004, the European Commission issued the M/350 EN Standardisation Mandate to CEN for the development of horizontal standardized methods for the assessment of the integrated environmental performance of buildings [13]. The work of CEN/TC 350 
resulted in the publication in 2011 of European Standard EN 15978 [14] for the assessment of the environmental performance of buildings, and one year later, European Standard EN 15804 [15] for the development of environmental product declarations (EPD) of building products. EPD is based on the life cycle assessment (LCA) method, standardized in the standards ISO 14040 [16] and ISO 14044 [17], used to assess the environmental impacts of buildings during production, construction, use-also including repair and replacement, and end of life. EPD complies with the standard ISO 14025 [18]. The EPD, also known as type III environmental declaration, is meant to deliver transparent, reliable, quantified, and comparable information on products' environmental impact during their life cycle $[19,20]$. Many different EPD's programs operate by Product Category Rules (PCRs), and EPDs vary in their data quality and specificity, often leading to misleading comparisons [21-26]. Unfortunately, the use of data presented in EPD's is still limited. They are not mandatory but used voluntarily. Several multicriterion systems exist to assess building sustainability worldwide, such as BAMB, BREEAM, CASBEE, DGNB, Green Globes, HQE, LEED, ÖGNI, SBTool, TQB, etc. [27-30]. Additionally, manufacturers of building materials use data on the environmental impact of products in business-to-business (B2B) communication, including marketing purposes, preparation of offers for tenders (Green Public Procurement), and fulfilling customers' requirements [31].

Regardless of the standardization work carried out at CEN/TC 350 in 2011, the European Commission launched the Single Market for Green Products Initiative. The Product Environmental Footprint (PEF) and Organization Environmental Footprint (OEF) methods to measure environmental performance were proposed. Both PEF and OEF apply to the construction. They were the subject of pilot studies with 280 volunteering companies and organizations in 2013-2018 [32]. Based on the testing results, the EC launched in 2020 A new Circular Economic Action Plan for a Cleaner and More Competitive Europe [33], one of the European Green Deal [34] blocks. At the beginning of 2020, the comprehensive review of EPD and PEF, showing that the methods have very distinct requirements that compare results or the alternate use of PEFs and EPDs is impossible, was published [35]. To align the environmental reporting approaches, the European Commission issued an amendment mandate $\mathrm{M} / 350$ [36] to require the revision of EN 15804, including aligning with the PEF methodology. As a result, the new version of EN 15804+A2, setting new rules for the EPD of construction products, was published in July 2019 [37]. The new version of EN 15804 will be mandatory from July 2022.

The understanding and implementation of the principles of sustainable development face numerous obstacles all over the world. For example, the question of the scale and level at which should undertake activities in this field is still open. On 11 December 2019, the European Commission, recognizing the need to intensify actions in the field of sustainable development, presented a new ambitious action plan for a climate-neutral Circular Economy in which economic growth does not depend on the consumption of resources [34]. The Circular Economy reduces pressure on natural resources and is a prerequisite for achieving the 2050 climate neutrality goal [38,39]. An essential element of the European strategy is to promote a holistic approach based on the life cycle of the sustainable development of construction products and buildings [40]. The low level of awareness of the links between the economy, society, and the environment is one of the main barriers to sustainable development. The recently published results of research conducted among Polish consumers of the construction industry indicate a strong need to educate society in the Circular Economy [41].

From the perspective of producers, it should also be noted that assessing the environmental impact of construction products is related to the continuous improvement of their own production and procurement processes [42]. Objective assessment of the environmental impact requires it to be carried out based on production data on an industrial scale. It is also essential to create a construction supervision process that would ensure compliance with the set requirements [43]. Knowledge of the environmental impact of construction 
products is also fundamental to achieving sustainable development goals in many other dimensions [43].

Although the scientific literature on the environmental impact of products is extensive, the number of publications related to building materials is limited [44,45]. This article presents the case-study results of the environmental impact assessment of premixed gypsum-based plasters for the plastering of walls and ceilings for interior application. Premixed gypsum plasters are commonly used in modern construction. Nowadays, in Europe, the demand for Fuel Gas Desulfurization (FGD) gypsum is greater than the production capacity of a combined heat and power plant. This product becomes a valuable coproduct in the production of heat and electricity. The reaction that takes place in several stages in a desulfurization plant, it can be simply written by the equation:

$$
\mathrm{CaCO}_{3}+2 \mathrm{H}_{2} \mathrm{O}+\mathrm{SO}_{2}+1 / 2 \mathrm{O}_{2} \rightarrow \mathrm{CaSO}_{4} \cdot 2 \mathrm{H}_{2} \mathrm{O}+\mathrm{CO}_{2}
$$

Natural gypsum and FGD gypsum are used as binders in gypsum plasters. Commonly in the production of building materials, vast amounts of natural resources are used. As a rule, the use of construction products is generating significant amounts of waste. It is crucial for the above reasons to know what environmental consequences are associated with building material production. Each publication presenting data on the environmental impact of construction material should be treated as an innovation in construction [46]. This article focuses on presenting the environmental impact of plasters based on natural and FGD gypsum. Knowledge of the environmental burden on construction products allows investors, architects, designers, and contractors to choose the right environmental aspect solution. The presentation of data on the environmental impact obtained based on actual data relating to a large and thus representative scale of production is essential for popularizing the principles of sustainable development, including Sustainable Development Goals (SDGs) Number 9, "Industry, innovation and infrastructure," and Number 11, "Sustainable cities and communities." Commonly in the production of building materials, vast amounts of natural resources are used. As a rule, the use of building materials is generating significant amounts of waste.

\section{Materials and Methods}

\subsection{Gypsum}

Gypsum is one of the essential mineral binding materials used in construction. Gypsum has been used as a building material for thousands of years. Nowadays, two gypsum sources are of industrial importance in the construction sector: natural gypsum and gypsum from flue gas desulfurization processes in power plants using hard coal or lignite (FGD gypsum). The physical and chemical properties of natural gypsum and FGD gypsum are similar, and there are no significant differences between them. Natural gypsum has a lower purity than FGD gypsum (the wet limestone scrubbing of flue gas contains sulfur dioxide) due to many years of geological process formation. Gypsum of natural origin has various types of impurities. FGD gypsum differs in color from grayish-yellow to grayish-white, depending on the type of coal (hard or brown) and the mineral's degree of sulfur content.

In nature, gypsum is found in many countries on different continents. Poland has extensive resources of gypsum and anhydrite, amounting to approximately 261 million tons. Out of 15 documented deposits of gypsum and anhydrite in Poland, five are currently exploited: Borków-Chwałowice, Leszcze, Lubichów, Nowy Lad, and Nowy LądRadłówka [47]. In Poland, the first flue gas desulfurization installation at the Bełchatów power plant started into operation in 1994, and at that time, FGD gypsum production began [47]. Nowadays, Poland is a leader in Europe regarding the percentage of electricity produced based on coal. In 2019, this share was less than $80 \%$, with the average for all European Union countries at 17.4\% [48]. In Europe in 2016, the production of coal combustion products (fly ash and flue gas desulfurization products) was 40.33 million tons, of which 9.92 million tons was FGD gypsum [49]. In Poland, 3.08 million tons of FGD gypsum were produced in 2019 [50]. 
According to the European Union's plans, coal-fired power plants will end their life before 2050 [34]. Based on an agreement signed between the Polish government and mining trade unions in Poland, the last hard coal mine will be closed in 2049 [51].

Considering the prospect of decommissioning coal-fired energy in the European Union, the number of combustion coproducts, including FGD gypsum, will be systematically decreasing in the next thirty years to a simultaneous constant demand for them by other industries, including the production of building materials. This situation is a specific ecological paradox resulting from the modern human domination project over nature [52]. Implementing the civilization development program (energy production with the use of coal) has led to environmental threats to the foundations of human existence (emission of sulfur dioxide harmful to humans, animals, and plants). As part of reducing the energy industry's negative impact on the environment, a flue gas desulfurization technology was introduced. FGD gypsum is formed, and $\mathrm{CO}_{2}$ is emitted into the atmosphere instead of sulfur dioxide. Initially, FGD gypsum was waste, but as a result of many years of waste management policy, it has become a desirable raw material for building materials and in the cement industry. In the coming years, in connection with EU goals aimed at abandoning coal-based energy production, it will reduce and finally lead to the disappearance of FGD gypsum production. The construction industry and cement producers will be forced to look for an alternative-replacing FDG gypsum with a raw material of natural origin or creating other alternative building materials that use binders other than gypsum. The situation in terms of the future availability of FGD gypsum in other continents is entirely different than in Europe. Currently, in China, it is believed that FGD gypsum will replace natural gypsum for construction processes [53]. Today's FGD gypsum consumption in China is relatively low due to the lack of reusing methods [54]. Nowadays, crude gypsum $\left(\mathrm{CaSO}_{4} \cdot 2 \mathrm{H}_{2} \mathrm{O}\right)$, whether of natural origin or from the flue gas desulfurization process, is used as a regulator of cement setting time [55]. FGD gypsum is also used in agriculture [56]. After calcination, gypsum is used to produce plasters, adhesives, plasterboards, and prefabricated stucco elements [55].

\subsection{Gypsum Plasters}

In the EU, premixed gypsum plasters characteristics and performance are specified in EN 13279-1 [57]. Whether it is for manual or mechanical applications, gypsum plasters are used for plastering walls and ceilings inside buildings. They are applied as a finishing layer that can be decorated. Producers of gypsum plasters, that use the requirements specified in EN 13279-1 to assess and verify the constancy of the performance of the offered products, have the option to declare up to two groups of gypsum plasters: gypsum plasters-B or gypsum plasters for special purposes-C. Types of gypsum plasters, according to EN 13279-1, are specified in Table 1.

The research subject described in this paper comprises three gypsum plasters for machine applications classified according to EN 13279-1 as B4/50/2, which means that they are lightweight gypsum building plasters (B4) with an initial setting time $>50 \mathrm{~min}$ and a compressive strength $\geq 2.0 \mathrm{~N} / \mathrm{mm}^{2}$. The first two gypsum plasters, produced at the Konin plant and the Leszcze plant, contain FGD gypsum. Figure 1 shows a schematic view of the gypsum plaster production process. The crude gypsum delivered to the Konin plant is obtained as a coproduct in fumes desulfurization at the nearby Pątnów power plant (less than $500 \mathrm{~m}$ ). The crude gypsum delivered to the Leszcze plant is obtained at the Kozienice power plant located about $190 \mathrm{~km}$ from the Leszcze plant. The third gypsum plaster, based on natural gypsum, is produced in the plant in Leszcze, located in the vicinity of the raw gypsum quarry Leszcze (also about $500 \mathrm{~m}$ away).

In Konin's plant, as a heating agent in the calcination process, saturated water vapor from the nearby located Patnów power plant is used. This innovative gypsum calcination process provides no emission of $\mathrm{CO}_{2}, \mathrm{NO}_{\mathrm{x}}, \mathrm{SO}_{\mathrm{x}}$, and combustion dust. 
Table 1. Types of gypsum plasters, according to EN 13279-1 [57].

\begin{tabular}{lc}
\hline Designation & Notation \\
\hline Gypsum plaster & $\mathrm{B}$ \\
Gypsum building plaster & $\mathrm{B} 1$ \\
Gypsum-based building plaster & $\mathrm{B} 2$ \\
Gypsum-lime building plaster & $\mathrm{B} 3$ \\
Lightweight gypsum building plaster & $\mathrm{B} 4$ \\
Lightweight gypsum-based building plaster & $\mathrm{B} 5$ \\
Lightweight gypsum-lime building plaster & $\mathrm{B} 6$ \\
Gypsum plaster for plasterwork with & $\mathrm{B} 7$ \\
enhanced surface hardness & $\mathrm{C}$ \\
Gypsum plaster for special purposes & $\mathrm{C} 1$ \\
Gypsum plaster for fibrous plasterwork & $\mathrm{C} 2$ \\
Gypsum mortar & $\mathrm{C} 3$ \\
Gypsum plaster & $\mathrm{C} 4$ \\
Thermal insulation plaster & $\mathrm{C} 5$ \\
Fire protection plaster & $\mathrm{C} 6$ \\
Thin coat plaster, finishing product & $\mathrm{C} 7$ \\
Finishing product &
\end{tabular}

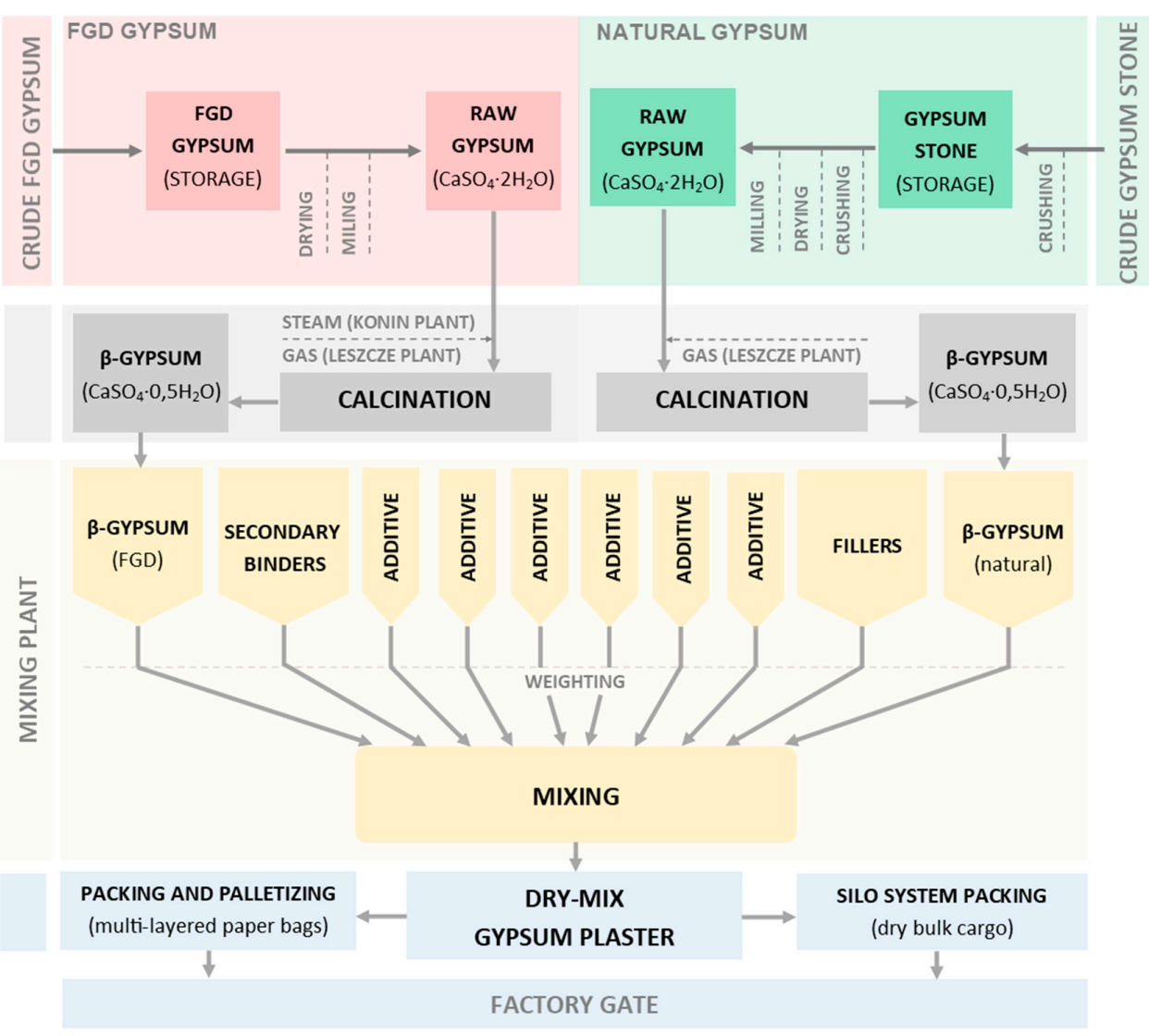

Figure 1. Schematic view of the gypsum plaster production process.

The Konin plant consists of a gypsum calcination unit, a mixing line, and a packing and palletizing line. The raw material $\left(\mathrm{CaSO}_{4} \cdot 2 \mathrm{H}_{2} \mathrm{O}\right)$ is transported directly from the Patnów power plant through a converted belt conveyor to a calcination plant. After calcination, gypsum $\left(\mathrm{CaSO}_{4} \cdot 1 / 2 \mathrm{H}_{2} \mathrm{O}\right)$ is transported to silos and then to the mixing plant.

The production plant in Leszcze is complex, consisting of a crude gypsum stone storage, calcination units (one for FGD gypsum and the second for natural gypsum), and a gypsum mixing plant. Natural gypsum stone after the excavation is first precrushed and 
then transported to the warehouse. In the next step, precrushed gypsum stones are treated mechanically (final crushing, grinding, and drying) and next dehydrated in the calciner. Afterward, gypsum is transported to silos and pneumatically transported to the mixing plant subsequently.

\subsection{Life Cycle Assessment (LCA)—General Rules Applied}

For this study, the environmental impact was assessed using the LCA method for three gypsum plasters, one based on natural gypsum and two others on FGD gypsum. All products under normal conditions have an expected service life of well over 50 years. The original goal for performing the LCA study was B2B communication [58]. The data used in the calculations relate to 2017 (EPD released in May 2019) production in two locations in different regions of Poland: Leszcze (natural gypsum-based plaster and FGD gypsum-based plaster) and Konin (FGD gypsum-based plaster). The production volume of three gypsum plasters during 2017 was equal to about three-hundred thousand tons. It corresponds to around 11 million square meters of internal walls of the building, assuming $3 \mathrm{~cm}$ thick plaster and approximately 22 million square meters of inner ceilings with a $1.5 \mathrm{~cm}$ thickness. EPD type III was developed under EN 15804+A1 [59], and its content was verified under ISO 14025 [18] by an independent third body. The life cycle that was the subject of the analysis covered Modules A1 to A3, i.e., from the extraction of raw material to the finished product delivered to the factory gate, where A1-extraction, the processing of raw materials, and the processing of secondary material, including recycling processes, A2 - transport to the manufacturer, and A3-production. Manufacturing of the plasters begins from delivering gypsum stone or FDG gypsum to the production plants. For modeling environmental burdens associated with the A1 module-extraction of the raw materials (material consumption, energy consumption, transportation, emissions, and waste), generic LCI data originating from the verified Ecoinvent database and specific EPDs compliant with EN 15804 and ISO 14025 were used. Environmental impacts occurring in A2 and A3 modules were calculated based on the production plants' data inventory. For LCA calculations, data on annual electricity and energy resources consumption were used. The allocation rules used for the EPD [58] were based on general ITB PCR A [60]. The allocation was done on a product mass basis. All impacts from raw materials extraction were allocated in the A1 module, including materials and energy consumption, transportation, emissions, and waste resulting from the gypsum plasters' production. Municipal waste and wastewater of Leszcze and Konin factories were allocated to Module A3. Energy supplies for entire production processes were inventoried. Emissions in the factories were measured and were allocated to Module A3. All significant parameters from gathered production data were considered in the assessment, i.e., all material used per formulation, utilized thermal energy, internal fuel, and electric power consumption, direct production waste, and all available emission measurements. It was assumed that the total sum of omitted processes does not exceed 5\% of all impact categories. Following EN 15804+A1 [59], machines and facilities (capital goods) required for and during production were excluded, as was the transportation of employees.

Apart from natural gypsum (Leszcze) and FGD gypsum (Konin), other raw materials used in larger quantities, such as lime, perlite, and different fillers, were of local origin, while additives and packaging materials originate from more distant suppliers. Data on transporting the various products to the manufacturing plants were collected and modeled for the assessor's factory. Means of transport include trucks, and Polish and European fuel averages were applied.

The data for the processes came from the following databases: Ecoinvent version 3.5, specific EPDs, ELCD, Ullmann's, ITB-Data. Detailed data quality analysis was a part of the external ISO 14,001 audit. Characterization factors are CML version 4.2 based on EN 15804+A1 [59] version (PN-EN 15804+A1:2014-04). 


\section{Results}

Table 2 shows the environmental characteristics of premixed gypsum plasters based on FGD or natural gypsum calculated for $1 \mathrm{~kg}$, of:

- Global warming potential (GWP);

- Depletion potential of the stratospheric ozone layer (ODP);

- $\quad$ Acidification potential of soil and water (AP);

- Eutrophication potential (EP);

- $\quad$ Formation potential of tropospheric ozone (POCP);

- Abiotic depletion potential (ADP-elements; ADP-el.) for nonfossil resources;

- Abiotic depletion potential (ADP-fossil fuels; ADP-ff.) for fossil resources;

- Total use of renewable primary energy resources (primary energy and primary energy resources used as raw materials) (PERT);

- $\quad$ Total use of nonrenewable primary energy resources (primary energy and primary energy resources used as raw materials) (PENRT).

Table 2. Environmental characteristics of unpacked premixed gypsum plasters (loaded into silos, which are then transported to construction sites) based on flue gas desulfurization (FGD) gypsum (Konin and Leszcze plant) and natural gypsum (Leszcze plant) calculated in the year 2019 (data from 2017) [58].

\begin{tabular}{|c|c|c|c|}
\hline \multirow[b]{2}{*}{ Indicator (Unit) } & \multicolumn{3}{|c|}{ A1-A3 } \\
\hline & $\begin{array}{l}\text { FGD Gypsum-Based } \\
\text { Plaster (Konin Plant) }\end{array}$ & $\begin{array}{l}\text { FGD Gypsum-Based } \\
\text { Plaster (Leszcze Plant) }\end{array}$ & $\begin{array}{l}\text { Natural Gypsum-Based } \\
\text { Plaster (Leszcze Plant) }\end{array}$ \\
\hline \multicolumn{4}{|c|}{ Environmental impacts, $1 \mathrm{~kg}$ of product } \\
\hline GWP (kg CO 2 eq.) & $6.73 \times 10^{-2}$ & $7.32 \times 10^{-2}$ & $1.36 \times 10^{-1}$ \\
\hline ODP (kg CFC 11 eq.) & $8.67 \times 10^{-9}$ & $8.67 \times 10^{-9}$ & $8.45 \times 10^{-9}$ \\
\hline $\mathrm{AP}\left(\mathrm{kg} \mathrm{SO} \mathrm{S}_{2}\right.$ eq. $)$ & $2.26 \times 10^{-4}$ & $1.87 \times 10^{-4}$ & $2.18 \times 10^{-4}$ \\
\hline $\mathrm{EP}\left(\mathrm{kg}\left(\mathrm{PO}_{4}\right)_{3}-\mathrm{eq}.\right)$ & $7.57 \times 10^{-6}$ & $4.66 \times 10^{-6}$ & $4.93 \times 10^{-6}$ \\
\hline POCP (kg Ethene eq.) & $2.86 \times 10^{-5}$ & $2.16 \times 10^{-5}$ & $3.34 \times 10^{-5}$ \\
\hline ADP-el. (kg SB eq.) & $3.23 \times 10^{-4}$ & $3.23 \times 10^{-4}$ & $2.94 \times 10^{-4}$ \\
\hline ADP-ff. (MJ) & $6.82 \times 10^{-1}$ & $7.61 \times 10^{-1}$ & $1.24 \times 10^{0}$ \\
\hline \multicolumn{4}{|c|}{ Environmental aspects related to the consumption of raw materials, $1 \mathrm{~kg}$ of product } \\
\hline PERT (MJ) & $8.76 \times 10^{-1}$ & $7.19 \times 10^{-1}$ & $3.06 \times 10^{-2}$ \\
\hline PENRT (MJ) & $7.49 \times 10^{-1}$ & $8.33 \times 10^{-1}$ & $1.31 \times 10^{0}$ \\
\hline
\end{tabular}

Figure 2 presents data in the form of a compass graph. The presented data are proportional to each indicator's value to illustrate the interrelationships between the analyzed environmental impacts for individual gypsum plasters.

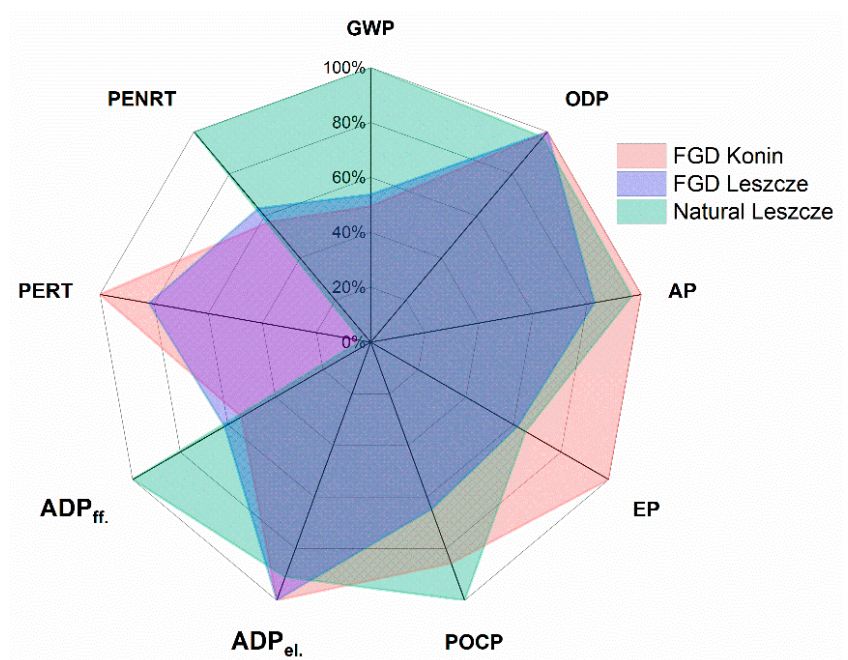

Figure 2. Environmental impact indicators of gypsum plasters based on FGD gypsum (Konin and Leszcze plant) and natural gypsum (Leszcze plant). 


\section{Discussion}

Comparing the GWP values (Modules A1-A3) for the three analyzed plasters shows that gypsum plaster based on natural gypsum has a higher environmental burden. The difference between plasters based on FGD gypsum and the natural one in GWP is significant. The product's load based on natural gypsum is $85.8 \%$ higher than the plaster based on FGD gypsum produced in the Leszcze production site and slightly more than twice $(102 \%)$ a similar plaster based on FGD gypsum from the Konin plant. Considering GWP for natural gypsum-based products, a significant environmental burden is associated with the mining from the quarry and crushing of the stone. For gypsum plasters based on FGD, gypsum mining and crushing do not exist.

The GWP of plaster based on FGD gypsum in the Leszcze is higher by $8.0 \%$ $\left(5.9 \times 10^{-3} \mathrm{~kg} \mathrm{CO} 2\right.$ eq.) than the corresponding product from the Konin location. In terms of other environmental impacts, slight differences are also observed between the FGD gypsum-based plasters from the Leszcze and Konin production plants, which results from the specificity of each location. In terms of GWP, the utilization of FGD gypsum in gypsum production is beneficial compared to natural gypsum. As it was already mentioned, the production of FGD gypsum is limited and will be smaller each year in the future in Poland and worldwide due to carbon dioxide emissions restrictions [48]. Despite the growing awareness of the importance of sustainable development issues and the significantly increasing demand for data/indicators in construction, their number and quality are still insufficient. In gypsum plasters commonly used in EU countries, there is a surprisingly small number of published EPDs. According to the available EPDs, the GWP value (for Modules A1-A3) varies between 0.078 and $0.151 \mathrm{~kg} \mathrm{CO}_{2}$ eq. [61-63]. EPD's communication target group is business to business. Therefore, it is important to provide information: we have an environmental declaration, i.e., we care about the environment, and we provide primary data about the product. However, the analysis of FGD gypsum's impact on the product (premixed gypsum plaster) to natural gypsum is beyond EPD's holders' interest. The difference between the GWP values for gypsum plasters based on natural gypsum and FGD gypsum is more significant than the observed difference between carbon dioxide emissions related to the manufacturing of calcined natural gypsum and FGD gypsum in the Czech Republic [64]. For FGD gypsum, $105.3 \mathrm{~kg} \mathrm{CO}_{2} / \mathrm{t}$ was recorded, i.e., a $25.2 \%$ lower value than the natural one [64]. In the range of the stratospheric ozone layer depletion potential (ODP), determining the quantitative impact of gypsum plaster on the destruction of the ozone layer, no significant differences were observed between products based on FGD gypsum and natural gypsum. For the acidification potential of soil and water (AP) expressed as $\mathrm{SO}_{2}$ equivalent to the emission of $\mathrm{SO}_{2}, \mathrm{NO}_{\mathrm{x}}, \mathrm{HCl}, \mathrm{NH}_{3}$, and HF, there are no significant differences between plasters based on natural and FGD gypsum observed. In the case of eutrophication potential (EP), quantitatively determining the impact on the accumulation of organic matter in waters, differences were observed between the localization of production (Konin and Leszcze). In the same location (Leszcze), no significant differences were observed between the plasters based on FGD and natural gypsum. The value of the formation potential of tropospheric ozone (POCP), determining the relative abilities of volatile organic compounds to produce ground-level ozone, for natural-based gypsum plaster is higher than for FGD-based ones. The gypsum source slightly affects the value of the abiotic depletion potential (ADP-elements) for nonfossil resources. In the scope of the abiotic depletion potential (ADP-fossil fuels) for fossil resources, the value of the indicator of natural-based gypsum plaster is significantly higher than for FGD gypsum-based ones. For gypsum plasters based on FGD gypsum, the total use of renewable and total nonrenewable primary energy sources is similar (Konin- -0.876 and $0.749 \mathrm{MJ} / \mathrm{kg}$ and Leszcze -0.719 and $0.833 \mathrm{MJ} / \mathrm{kg}$, respectively for PERT and PENRT). In the case of plaster based on natural gypsum, the total use of nonrenewable primary energy resources (PERT) is much higher $(1.31 \mathrm{MJ} / \mathrm{kg})$ than the total use of renewable primary energy resources (PENRT) equal to $0.0306 \mathrm{MJ} / \mathrm{kg}$. 
Although gypsum is a commonly used mineral binder and environmental impact issues are essential, gypsum was analyzed in terms of environmental impacts only rarely, and sufficiently accurate data are still missing [64]. Of course, the advantage of using FGD gypsum over natural gypsum also in terms of environmental impact is known, for example, for wallboards $[65,66]$. However, it is not always expressed in a way that is easy to compare with others. However, the message: "using 7.5 Mg of FGD gypsum instead of natural one in wallboard manufacturing resulted in 2007 in reducing $83,000 \mathrm{Mg}$ of $\mathrm{CO}_{2}$ eq., with an additional cost savings of USD 49 to USD 64 million" [65] is convincing. Another example is the comparison of the environmental load of the natural gypsum board with the FGD gypsum board for the sum of the five impact categories (normalized and weighted calculation): GWP, AP, POCP, ADP, and human toxicity (HT) [66]. This comparison shows that the total environmental load of the natural gypsum board is $6 \%$ higher than the FGD gypsum board [66]. It is also worth noting the use of recycled gypsum. LCA studies performed for the production of recycled gypsum (from plasterboard and powder waste) showed that the environmental burden is lower than $40 \%$ in all the studied impact categories compared to the natural gypsum production [67]. Gypsum-based products, including gypsum plasters, are also important due to the need to develop technologies other than common cement-based construction materials due to the need to reduce carbon dioxide emissions from Portland production clinker [68]. Nowadays, in Poland, the GWP (Modules A1-A3) of Portland cement varies from $482 \mathrm{~kg} \mathrm{CO}$ eq./t for CEM III to $889 \mathrm{~kg}$ $\mathrm{CO}_{2}$ eq. $/ \mathrm{t}$ for CEM I [69]. The GWP related to gypsum's calcination process is 4-8 times smaller than for Portland cement depending on the nature of gypsum (natural or FGD product), purity, manufacturing techniques, transport distances, and other factors. It is also worth noting that gypsum can change its properties through a reversible hydration reaction, and due to that, gypsum products can contribute to a Circular Economy [70]. Knowledge of gypsum plasters' environmental properties is essential to build environmental awareness of the consumer and support low-emission building design development. It is also essential to further design and develop new products that better meet the sustainability criteria than today's solutions.

\section{Conclusions}

The demand for verified and understandable environmental indicators for the average recipient increases from year to year. Knowing them is essential to develop environmentally friendly construction even though, since 2013, under CPR in the European Union countries, one of the seven basic requirements in construction is sustainable development in assessing and verifying the constancy of performance of construction products is not subject to mandatory assessment in this regard.

In this study, the following nine environmental indicators were defined: GWP, ODP, AP, EP, POCP, ADP-elements, ADP-fossil fuels, PERT, and PERNT of gypsum plasters based on natural gypsum and FGD gypsum. In general, gypsum products are characterized by a lower negative environmental impact than commonly used cement products. Premixed gypsum plasters based on natural gypsum are characterized by an almost twice higher GWP value (Modules A1-A3) than similar premixed plasters based on FGD gypsum. Additionally, in the case of the abiotic depletion potential (ADP-fossil fuels) for fossil resources, the value of the natural-based gypsum plaster indicator is significantly higher than for FGD gypsum-based ones. For gypsum plasters based on FGD gypsum, the total use of renewable primary energy sources is much higher than in plaster based on natural gypsum. Natural gypsum-based plaster is characterized by a much higher value of total use of nonrenewable primary energy resources (PENRT) than products based on FGD gypsum. FGD gypsum is a product of the desulfurization of flue gases generated in power plants using fossil fuels (coal). In the past, FGD gypsum was a waste, and due to its management by man, it is now a desirable raw material that is experiencing little availability from year to year. We can call this situation "the ecological paradox." In other words, FGD gypsum, like other waste, is a measure of the success and failure of humanity in civilization. 
Products' whole supply chain's environmental implications have to be known and considered. Nowadays, to achieve more sustainable production and consumption patterns, we have to know and consider the products' whole supply chain's environmental implications. Sustainability assessment and sustainability indicators can and should be powerful decision-supporting tools that foster sustainable development, not only in the construction sector. Considering the factors mentioned earlier, as much data as possible on construction products' environmental impact must be widely available. We should support all initiatives helping to achieve this goal, including scientific articles. Each EPD or scientific article is facilitating communication. A few years from now, the environmental impact will be part of building materials' mandatory AVCP.

Author Contributions: Conceptualization: J.M.; formal analysis: S.C., M.H., M.P. and J.T.; investigation: E.B., M.H., B.M., J.T. and J.M.; methodology: S.C., B.M., M.P., J.T. and J.M.; project administration: J.M.; resources: E.B., S.C., M.H. and J.T.; supervision: J.M.; validation: M.P. and J.T.; visualization, B.M.; writing—original draft preparation: J.M.; writing-review and editing, J.M. and B.M. All authors have read and agreed to the published version of the manuscript.

Funding: J.M. was partially supported by the Smart Growth Operational Program 2014-2020 (Project number POIR.02.01.00-00-0350/16).

Institutional Review Board Statement: Not applicable.

Informed Consent Statement: Not applicable.

Data Availability Statement: Not applicable.

Conflicts of Interest: The authors declare no conflict of interest.

\section{References}

1. World Meteorological Organization. State of the Global Climate 2020. Provisional Report. Available online: https: / library.wmo. int/doc_num.php?explnum_id=10444 (accessed on 27 December 2020).

2. Le Quéré, C.; Jackson, R.B.; Jones, M.W.; Smith, A.J.; Abernethy, S.; Andrew, R.M.; De-Gol, A.J.; Willis, D.R.; Shan, Y.; Canadell, J.G.; et al. Temporary reduction in daily global $\mathrm{CO}_{2}$ emissions during the COVID-19 forced confinement. Nat. Clim. Chang. 2020, 10, 647-653. [CrossRef]

3. World Meteorological Organization. WMO Greenhouse Gas Bulletin-No. 16: The State of Greenhouse Gases in the Atmosphere Based on Global Observation through 2019. Available online: https://library.wmo.int/doc_num.php?explnum_id=10437 (accessed on 27 December 2020).

4. Krausmann, F.; Gingrich, S.; Eisenmenger, N.; Erb, K.H.; Haberl, H.; Fischer-Kowalski, M. Growth in global materials use, GDP and population during the 20th century. Ecol. Econ. 2009, 68, 2696-2705. [CrossRef]

5. Global Alliance for Buildings and Construction, International Energy Agency and the United Nations Environment Programme. 2019 Global Status Report for Buildings and Construction: Towards a Zero-emission, Efficient and Resilient Buildings and Construction Sector. Available online: https://www.worldgbc.org/news-media/2019-global-status-report-buildings-andconstruction (accessed on 27 December 2020).

6. United Nations Environment Programme. 2020 Global Status Report for Buildings and Construction: Towards a Zero-emission, Efficient and Resilient Buildings and Construction Sector. Available online: https://globalabc.org/news/launched-2020-globalstatus-report-buildings-and-construction (accessed on 27 December 2020).

7. Peters, G.P.; Andrew, R.M.; Canadell, J.G.; Friedlingstein, P.; Jackson, R.B.; Korsbakken, J.I.; Le Quéré, C.; Peregon, A. Carbon dioxide emissions continue to grow amidst slowly emerging climate policies. Nat. Clim. Chang. 2020, 10, 3-6. [CrossRef]

8. Pomponi, F.; Crawford, R.; Stephan, A.; Hart, J.; D'Amico, B. The 'building paradox': Research on building-related environmental effects requires global visibility and attention. Emerald Open Res. 2020, 2, 50. [CrossRef]

9. Röck, M.; Saade, M.R.M.; Balouktsi, M.; Rasmussen, F.N.; Birgisdottir, H.; Frischknecht, R.; Habert, G.; Lützkendorf, T.; Passer, A. Embodied GHG emissions of buildings-The hidden challenge for effective climate change mitigation. Appl. Energy 2020, 258, 114107. [CrossRef]

10. United Nations. World Urbanization Prospects: The 2018 Revision. Available online: https://www.un.org/en/events/citiesday/ assets/pdf/the_worlds_cities_in_2018_data_booklet.pdf (accessed on 27 December 2020).

11. Scherz, M.; Passer, A.; Kreiner, H. Challenges in the achievement of a Net Zero Carbon Built Environment-A systemic approach to support the decision-aiding process in the design stage of buildings. IOP Conf. Ser. Earth Environ. Sci. 2020, 588, 032034. [CrossRef]

12. Regulation (EU) No. 305/2011 of the European Parliament and of the Council. Available online: https:/ / eur-lex.europa.eu/legalcontent/EN/TXT/?uri=CELEX:32011R0305 (accessed on 28 December 2020). 
13. European Commission. M/350 EN Standardisation Mandate to CEN. In Development of Horizontal Standardized Methods for Assessment of the Integrated Environmental Performance of Buildings; European Commission: Brussels, Belgium, 2004.

14. European Committee for Standardization (CEN). EN 15978:2011 Sustainability of Construction Works-Assessment of Environmental Performance of Buildings-Calculation Method; European Committee for Standardization (CEN): Brussels, Belgium, 2012.

15. European Committee for Standardization (CEN). EN 15804:2012 Sustainability of Construction Works-Environmental Product Declarations-Core Rules for the Product Category of Construction Product; European Committee for Standardization (CEN): Brussels, Belgium, 2012.

16. International Organization for Standardization (ISO). ISO 14040:2006 Environmental Management-Life Cycle Assessment-Principles and Framework; ISO 14040:2006; International Organization for Standardization (ISO): Geneva, Switzerland, 2006.

17. International Organization for Standardization (ISO). ISO 14044:2006 Environmental Management-Life Cycle Assessment-Requirements and Guidelines; ISO 14040:2006; International Organization for Standardization (ISO): Geneva, Switzerland, 2006.

18. International Organization for Standardization (ISO). ISO 14025:2006 Environmental Labels and Declarations-Type III Environmental Declarations-Principles and Procedure; ISO 14040:2006; International Organization for Standardization (ISO): Geneva, Switzerland, 2006.

19. Bovea, M.D.; Ibáñez-Forés, V.; Agustí-Juan, I. Environmental product declaration (EPD) labeling of construction and building materials. In Eco-Efficient Construction and Building Materials: Life Cycle Assessment (LCA), Eco-Labelling and Case Studies; Woodhead Publishing: New York, NY, USA, 2014; pp. 125-150, ISBN 9780857097675.

20. Brinkmann, T.; Metzger, L. Ecological assessment based on environmental product declarations. In Progress in Life Cycle Assessment; Springer: Cham, Switzerland, 2018; pp. 21-31.

21. Rocha, C.; Camocho, D.; Sampaio, J.; Alexandre, J. Product-Service Development for Circular Economy and Sustainability Course; LNEG-Laboratório Nacional de Energia e Geologia, I.P.: Amodora, Portugal, 2020; ISBN 978-989-675-063-3.

22. Anderson, J.; Moncaster, A. Embodied carbon of concrete in buildings, Part 1: Analysis of published EPD. Build. Cities 2020, 1 , 198-217. [CrossRef]

23. Waldman, B.; Huang, M.; Simonen, K. Embodied carbon in construction materials: A framework for quantifying data quality in EPDs. Build. Cities 2020, 1, 625-636. [CrossRef]

24. Durão, V.; Silvestre, J.D.; Mateus, R.; De Brito, J. Economic valuation of life cycle environmental impacts of construction products-A critical analysis. IOP Conf. Ser. Earth Environ. Sci. 2019, 323, 012147. [CrossRef]

25. Miller, T.R.; Gregory, J.; Kirchain, R. Critical Issues When Comparing Whole Building \& Building Product Environmental Performance; MIT Concrete Sustainability Hub: Cambridge, MA, USA, 2016.

26. Passer, A.; Lasvaux, S.; Allacker, K.; De Lathauwer, D.; Spirinckx, C.; Wittstock, B.; Kellenberger, D.; Gschösser, F.; Wall, J.; Wallbaum, H. Environmental product declarations entering the building sector: Critical reflections based on 5 to 10 years' experience in different European countries. Int. J. Life Cycle Assess. 2015, 20, 1199-1212. [CrossRef]

27. Bitsiou, E.; Giarma, C. Parameters related to building components' life-cycle analysis in methods for buildings' environmental performance assessment. IOP Conf. Ser. Earth Environ. Sci. 2020, 410, 012066. [CrossRef]

28. Andersen, S.C.; Larsen, H.F.; Raffnsøe, L.; Melvang, C. Environmental product declarations (EPDs) as a competitive parameter within sustainable buildings and building materials. IOP Conf. Ser. Earth Environ. Sci. 2019, 323, 012145. [CrossRef]

29. Gelowitz, M.D.C.; McArthur, J.J. Investigating the efect of environmental product declaration adoption in LEED ${ }^{\circledR}$ on the construction industry: A case study. Procedia Eng. 2016, 145, 58-65. [CrossRef]

30. Berardi, U. Sustainability assessment in the construction sector: Rating systems and rated buildings. Sustain. Dev. 2012, 20, 411-424. [CrossRef]

31. Galindro, B.M.; Welling, S.; Bey, N.; Olsen, S.I.; Soares, S.R.; Ryding, S.-O. Making use of life cycle assessment and environmental product declarations. A survey with practitioners. J. Ind. Ecol. 2020, 24, 1-11. [CrossRef]

32. European Commission. Single Market for Green Products Initiative. Available online: https://ec.europa.eu/environment/eussd/ smgp/index.htm (accessed on 28 December 2020).

33. European Commission. Communication from the Commission to the European Parliament, the Council, the European Economic and Social Committee and the Committee of the Regions. A New Circular Economy Action Plan for a Cleaner and More Competitive Europe; European Commission: Brussels, Belgium, 2020; Available online: https: / / eur-lex.europa.eu/legal-content/EN/TXT/?qid=158393381438 6\&uri=COM:2020:98:FIN (accessed on 28 December 2020).

34. European Commission. The European Green Deal; European Commission: Brussels, Belgium, 2019.

35. Durão, V.; Silvestre, J.D.; Mateus, R.; de Brito, J. Assessment and communication of the environmental performance of construction products in Europe: Comparison between PEF and EN 15804 compliant EPD schemes. Resour. Conserv. Recycl. 2020, 156, 104703. [CrossRef]

36. European Commission. Amendment of Standardisation Mandate M/350 to CEN. Available online: https:/ / www.constructionproducts. org.uk/media/25413/scc-16-04-mandate_m350_2016-02-05_ec_final_version-002.pdf (accessed on 28 December 2020).

37. European Committee for Standardization (CEN). EN 15804:2012+A2:2019 Sustainability of Construction Works-Environmental Product Declarations-Core Rules for the Product Category of Construction Product; European Committee for Standardization (CEN): Brussels, Belgium, 2019.

38. Benachio, G.L.F.; Freitas, M.D.C.D.; Tavares, S.F. Circular economy in the construction industry: A systematic literature review. J. Clean. Prod. 2020, 260, 121046. [CrossRef] 
39. Vinante, C.; Sacco, P.; Orzes, G.; Borgianni, Y. Circular Economy Metrics: Literature Review and Company-Level Classification Framework. J. Clean. Prod. 2020, 288, 125090. [CrossRef]

40. Kylili, A.; Fokaides, P.A. Policy trends for the sustainability assessment of construction materials: A review. Sustain. Cities Soc. 2017, 35, 280-288. [CrossRef]

41. Tomaszewska, J. Polish Transition towards Circular Economy: Materials Management and Implications for the Construction Sector. Materials 2020, 13, 5228. [CrossRef] [PubMed]

42. Ströbele, B.; Lützkendorf, T. Communicating environmental information: Rethinking options for construction products. Build. Res. Inf. 2019, 47, 681-696. [CrossRef]

43. Mjakuškina, S.; Kavosa, M.; Lapina, I. Achieving Sustainability in the Construction Supervision Process. J. Open Innov. Technol. Mark. Complex. 2019, 5, 47. [CrossRef]

44. Meschede, C. The Sustainable Development Goals in Scientific Literature: A Bibliometric Overview at the Meta-Level. Sustainability 2020, 12, 4461. [CrossRef]

45. Czernik, S.; Marcinek, M.; Michałowski, B.; Piasecki, M.; Tomaszewska, J.; Michalak, J. Environmental Footprint of Cementitious Adhesives-Components of ETICS. Sustainability 2020, 12, 8998. [CrossRef]

46. Czarnecki, L.; Gemert, D. Innovation in construction materials engineering versus sustainable development. Bull. Pol. Acad. Sci. Tech. Sci. 2017, 65, 765-771. [CrossRef]

47. Szlugaj, J.; Naworyta, W. Analiza zmian podaży gipsu w Polsce w świetle rozwoju odsiarczania spalin w elektrowniach konwencjonalnych/Analysis of the Changes in Polish Gypsum Resources in the Context of Flue Gas Desulfurization in Conventional Power Plants. Gospod. Surowcami Miner. Miner. Resour. Manag. 2015, 31, 93-108. [CrossRef]

48. Chrzanowski, Z.; Baran, B.; Dudziak, M.; Katzor, R. Polska jako potencjalne źródło ubocznych produktów spalania (UPS) dla rynków europejskich. In Proceedings of the XXVI Międzynarodowa Konferencja Popioły z Energetyki, Sopot, Poland, 8-10 October 2019. (In Polish).

49. European Coal Combustion Products Association e.V. Production and Utilisation of CCPs in 2016 in Europe. 2020. Essen. Available online: http:/ /www.ecoba.com/ecobaccpprod.html (accessed on 29 December 2020).

50. Kowalczyk, G. Mniej Spalonego Wẹgla to Problem dla Branży Budowlanej. dziennik.pl. Available online: https:/ /gospodarka. dziennik.pl/news/artykuly/7797527, wegiel-branza-budowlana-gips-cement.html (accessed on 15 January 2021).

51. Ministry of State Assets. Available online: https://www.gov.pl/web/aktywa-panstwowe/w-katowicach-o-transformacjigornictwa (accessed on 29 December 2020).

52. Sadowski, R.F.; Kosieradzka-Federczyk, A. Paradoksy ekologiczne. In Odpady Miarą Sukcesu i Porażki Cywilizowanej Ludzkości; Krajowa Szkoła Administracji Publicznej: Warszawa, Poland, 2020; ISBN 9788361713197.

53. Yichao, Z.; Ying, W.; Jinghai, Z.; Jiaxi, L.; Tong, L. Basic characteristics and comprehensive utilization of FGD gypsum. IOP Conf. Ser. Earth Environ. Sci. 2020, 510, 052002. [CrossRef]

54. Ma, Y.; Nie, Q.; Xiao, R.; Hu, W.; Han, B.; Polaczyk, P.A.; Huang, B. Experimental investigation of utilizing waste flue gas desulfurized gypsum as backfill materials. Constr. Build. Mater. 2020, 245, 118393. [CrossRef]

55. Lushnikova, N.; Dvorkin, L. Sustainability of gypsum products as a construction material. In Sustainability of Construction Materials; Woodhead Publishing: New York, NY, USA, 2016; pp. 643-681, ISBN 9780081009956.

56. Watts, D.B.; Dick, W.A. Sustainable uses of FGD gypsum in agricultural systems: Introduction. J. Environ. Qual. 2014, 43, 246-252. [CrossRef]

57. European Committee for Standardization (CEN). EN 13279-1:2008 Gypsum Binders and Gypsum Plasters-Part 1: Definitions and Requirements; European Committee for Standardization (CEN): Brussels, Belgium, 2008.

58. Dolina Nidy. Environmental Product Declaration, Gypsum Plasters Alfa, Beta, Gamma, Zeta, Sprint, Tempo, Certificate No. 083/2019; Dolina Nidy: Warsaw, Poland, 2019.

59. European Committee for Standardization (CEN). EN 15804:2012+A1:2013 Sustainability of Construction Works-Environmental Product Declarations-Core Rules for the Product Category of Construction Product; European Committee for Standardization (CEN): Brussels, Belgium, 2013.

60. Building Research Institute (ITB). ITB-EPD General PCR Annex A v1.4 PN-EN 15804+A1:2014-04 Based; Building Research Institute (ITB): Warsaw, Poland, 2014.

61. Gypsum Industries Ltd. Environmental Product Declaration, Gyproc Finish Plaster; Gypsum Industries Ltd.: Dublin, Ireland, 2014.

62. Dalsan Alçı. Environmental Product Declaration, Gypsum Plasters; Dalsan Alçı: Ankara, Turkey, 2015.

63. Gips Geliştirilmiş İnşaat Malzemeleri Tic. A.Ş. Environmental Product Declaration, Gypsum Based Plasters; Gips Geliştirilmiş İnşaat Malzemeleri Tic. A.Ş.: Istanbul, Turkey, 2016.

64. Fořt, J.; Černý, R. Carbon footprint analysis of calcined gypsum production in the Czech Republic. J. Clean. Prod. 2018, 177, 795-802. [CrossRef]

65. Lee, J.C.; Bradshaw, S.L.; Edil, T.B.; Benson, C.H. Quantifying the benefits of flue gas desulfurization gypsum in sustainable wallboard production. In Proceedings of the World of Coal Ash (WOCA) Conference, Denver, CO, USA, 9-12 May 2011; pp. 9-12.

66. Peng, Z.G.; Ma, L.L.; Gong, X.Z. Comparison of life cycle environmental impacts between natural gypsum board and FGD gypsum board. Key Eng. Mater. 2014, 599, 15-18. [CrossRef]

67. Gawlicki, M. Belite in cements with low emission of $\mathrm{CO}_{2}$ during clinker formation. Cement Wapno Beton 2020, $25,348-357$. 
68. Pedreño-Rojas, M.A.; Fořt, J.; Černý, R.; Rubio-de-Hita, P. Life cycle assessment of natural and recycled gypsum production in the Spanish context. J. Clean. Prod. 2020, 253, 120056. [CrossRef]

69. Stowarzyszenie Producentów Cementu. Environmental Product Declaration, Cements CEM I, CEM II, CEM III, CEM IV, CEM V Produced in Poland, Certificate No 116/2020; Stowarzyszenie Producentów Cementu: Cracow, Poland, 2020.

70. Jiménez-Rivero, A.; García-Navarro, J. Management of end-of-life gypsum in a circular economy. In Advances in Construction and Demolition Waste Recycling; Woodhead Publishing: New York, NY, USA, 2020; pp. 69-79. 